\title{
The effect of antioxidant status on overall survival in renal cell carcinoma
}

\author{
Ivan Pavlović ${ }^{1}$, Snežana Pejić ${ }^{1}$, Sanja Radojević-Škodrić ${ }^{2}$, Ana Todorović ${ }^{1}$, Vesna Stojiljković ${ }^{1}$, \\ Ljubica Gavrilović ${ }^{1}$, Nataša Popović ${ }^{1}$, Gordana Basta-Jovanović ${ }^{2}$ Zoran Džamić ${ }^{3}$, Snežana B. Pajović ${ }^{1}$
}

\begin{abstract}
'Laboratory of Molecular Biology and Endocrinology, "Vinča” Institute of Nuclear Sciences, University of Belgrade, Belgrade, Serbia

${ }^{2}$ Institute of Pathology, School of Medicine, University of Belgrade, Belgrade, Serbia

${ }^{3}$ Clinic of Urology, Clinical Centre of Serbia, School of Medicine, University

of Belgrade, Belgrade, Serbia
\end{abstract}

Submitted: 12 June 2017

Accepted: 26 July 2017

Arch Med Sci 2020; 16 (1): 94-101

DOI: https://doi.org/10.5114/aoms.2019.86818

Copyright $\odot 2019$ Termedia \& Banach

\section{Abstract}

Introduction: The oxidative stress contributes to all three phases of carcinogenesis and represents a concomitant condition in renal cell carcinoma (RCC). RCC is the most common type of neoplasm of the kidney, and despite numerous studies the set of predictive and prognostic markers of survival are still unknown. The aim of our study was to examine the relation between antioxidant (AO) status and overall survival (OS) in RCC patients.

Material and methods: Our study included 95 patients with RCC, who underwent radical nephrectomy. We analysed the prognostic role of antioxidant enzymes (superoxide dismutase, catalase, glutathione peroxidase, glutathione S-transferase, glutathione reductase, glutathione, and malondialdehyde) and other clinicopathological factors (size, grade, stage, and histological subtype) on the OS of RCC patients.

Results: The 5 -year OS was $54.6 \%$. The survival analysis related to $\mathrm{AO}$ parameters showed no significant difference in survival of RCC patients. The concentration of malondialdehyde, an indicator of lipid peroxidation, also had no significant effect on the survival rate of RCC patients. Univariate and multivariate analysis confirmed the significance of clinicopathological parameters (size, $p<0.001$; Fuhrman grade, $p=0.001$, and stage, $p<0.001$ ) for patients' survival.

Conclusions: In our cohort of patients, different antioxidant parameters were not found to be predictors for OS of patients with RCC, who underwent radical nephrectomy.

Key words: renal cell carcinoma, oxidative stress, overall survival, prospective study.

\section{Introduction}

Renal cell carcinoma (RCC) is a heterogeneous disease that includes histological entities characterised by different aetiology, morphology, and outcome. Three histological subtypes: clear cell (ccRCC), papillary (pRCC), and chromophobe (chRCC) account for $85-90 \%$ of all RCC cases [1]. The incidence of RCC is constantly increasing in North America and Europe [2] with the exception of Finland and Estonia where it has been stable [3]. The majority of cases (80\%) occur after the age of

\author{
Corresponding author: \\ Ivan Pavlović BSc \\ Laboratory of \\ Molecular Biology \\ and Endocrinology \\ "Vinča" Institute \\ of Nuclear Sciences \\ University of Belgrade \\ Mike Petrovića-Alasa 12-14 \\ P.O. Box 522 \\ 11001 Belgrade, Serbia \\ Phone/fax: +381 116455561 \\ E-mail: pavlovic@vin.bg.ac.rs
}


40 years, and the incidence rate is higher among men compared with women $(3: 2)$ [4]. A reliable causative agent of RCC is still unknown, but existing evidence points to chromosomal defects contributing to its development [5]. Objective diagnostic biomarkers and effective targeted therapeutics are also lacking [6].

The intensive metabolic activity of tubular epithelial cells, glomerular cells, and activated macrophages make them the main generators of reactive oxygen species (ROS) in human kidneys [7]. At the subcellular level, ROS are produced in the process of oxidative phosphorylation in mitochondria and as a product of membrane-bound protein NADPH oxidases (NOX family) [8]. Under physiological conditions, ROS have a role as signalling molecules, and their physiological level is maintained by an antioxidant (AO) system. The AO system of the kidneys is based on small scavenging molecules like glutathione (GSH) and enzymes, which catalytically modify ROS into less harmful forms. Superoxide dismutase (SOD), catalase (CAT), and the glutathione peroxidase family (GPxs) are the main enzymes involved in $A O$ defence. Glutathione reductase (GR) and glutathione S-transferase (GST) are glutathionedependent enzymes, which additionally contribute to the AO ability of the kidneys [9]. Oxidative stress is a condition related to kidney cancer [10] and is mediated through a reduction in cellular antioxidant pool [11].

Efforts are still ongoing to find the set of predictive and prognostic markers of survival in patients with RCC [12]. Taking into account the significance of oxidative stress for all three phases of cancer development and the role of the AO system in preventing its process [13], we examined the relation between AO status and overall survival (OS) among RCC patients who underwent radical nephrectomy.

\section{Material and methods}

\section{Subjects}

We analysed 95 patients with RCC, who underwent radical nephrectomy in several Urology Clinics in Belgrade, Serbia, between 2009 and 2013. The study was performed in compliance with the ethical principles of the Declaration of Helsinki and all applicable national laws and regulations. The clinicopathological features of patients included age, gender, size, grade, stage, and histological classification. For tumour histology, the 2004 WHO classification [1] was used and tumours were graded according to the Fuhrman grading system [14]. OS time was determined from the surgery date until death or the last follow-up appointment. The follow-up period was 5 years (median: 38 months, IQR $=31-42$ months). The median age of patients at diagnosis was 62 years (IQR = 58-66.2 years).

\section{Specimens}

For the enzyme activity measurement, the tissue was washed in a saline solution (PBS) at $\mathrm{pH}$ 7.4 in order to remove blood cells. All samples were homogenised on ice in eight volumes of cold potassium phosphate buffer $\left(0.05 \mathrm{M} \mathrm{KH}_{2} \mathrm{PO}_{4}, 0.0001 \mathrm{M}\right.$ EDTA, $\mathrm{pH}$ 7.4) by using Ultra-Turrax Homogeniser (IKA ${ }^{\oplus}$ T10 basic ULTRA-TURRAX ${ }^{\oplus}$, IKA Werke $\mathrm{GmbH}$ \& Co.KG, Staufen, Germany) at 25,000 rpm for $15 \mathrm{~s}$ in four cycles. Homogenates were left overnight at $-70^{\circ} \mathrm{C}$ to disrupt cell membranes. The thawed homogenates were vortexed for $1 \mathrm{~min}$ and then centrifuged $\left(10000 \times \mathrm{g}, 15 \mathrm{~min}, 4^{\circ} \mathrm{C}\right)$ and the upper layer was collected and kept at $-70^{\circ} \mathrm{C}$ till the assay.

For GSH and total malondialdehyde (MDA) concentration measurement, the tissue was prepared as recommended by the kit producer (BIOXYTECH ${ }^{\circledR}$ GSH-420 ${ }^{\mathrm{TM}}$ and BIOXYTECH ${ }^{\circledast}$ MDA-586 ${ }^{\mathrm{TM}}$ respectively, OXIS International Inc., Foster City, CA, USA).

\section{Assays}

The protein concentration was measured with Pierce $^{\mathrm{TM}}$ BCA Protein Assay Kit (Thermo Fisher Scientific, Rockford, IL, USA). The method is based on a combination of the biuret reaction and colorimetric detection of cuprous cation $\left(\mathrm{Cu}^{+1}\right)$ with bicinchoninic acid (BCA). The cupric cation $\left(\mathrm{Cu}^{+2}\right)$ is reduced by the sample proteins in an alkaline medium to $\mathrm{Cu}^{+1}$. Two molecules of BCA react with one $\mathrm{Cu}^{+1}$ making a purple-coloured product that absorbs at $562 \mathrm{~nm}$. The protein concentration was expressed as $\mathrm{mg} / \mathrm{ml}$ of the sample.

Total SOD activity was measured using Superoxide Dismutase Assay Kit (Cayman Chemical Company, Ann Arbor, MI, USA). The assay is based on the reaction between tetrazolium salt and superoxide radicals $\left(\mathrm{O}_{2}^{\circ}\right)$, which results in formazan dye development. SOD inhibits this reaction by dismutation of $\mathrm{O}_{2}$, generated by xanthine oxidase. The intensity of formazan dye was measured at $450 \mathrm{~nm}$ using a microplate reader (Wallac1420 Victor ${ }^{2}$, PerkinElmer Inc., Waltham, MA, USA). One unit of SOD is defined as the amount of enzyme needed to exhibit $50 \%$ dismutation of superoxide radical.

Catalase activity measurement was performed by the method of Beutler (1984) [15]. The method is based on the ability of CAT to decompose hydrogen peroxide in an incubation mixture to water and oxygen. The incubation mixture contains $50 \mu \mathrm{l}$ of a Tris- $\mathrm{HCl}$ buffer (1 M Tris- $\mathrm{HCl}, 5 \mathrm{mM}$ EDTA, $\mathrm{pH}$ 8.0), $900 \mu \mathrm{l}$ of a substrate $\left(10 \mathrm{mM} \mathrm{H}_{2} \mathrm{O}_{2}\right)$ and 
$30 \mu \mathrm{l}$ of distilled water. The reaction starts after adding $20 \mu$ l of the sample. Decomposition of $\mathrm{H}_{2} \mathrm{O}_{2}$ was monitored for $3 \mathrm{~min}$ at $230 \mathrm{~nm}$ and $37^{\circ} \mathrm{C}$ using a spectrophotometer (UV Line 9400, SI Analytics $\mathrm{GmbH}$, Mainz, Germany). One unit of CAT activity is defined as the amount of enzyme that degrades $1 \mu \mathrm{mol}$ of $\mathrm{H}_{2} \mathrm{O}_{2}$ per minute under assay conditions. The extinction coefficient for $\mathrm{H}_{2} \mathrm{O}_{2}$ at $230 \mathrm{~nm}$ is $0.071 \mathrm{mM}^{-1} \mathrm{~cm}^{-1}$.

Glutathione peroxidase activity was assessed by the BIOXYTECH ${ }^{\oplus}$ GPX-340 ${ }^{\top M}$ Assay (Oxis International, Inc., Foster City, CA, USA). The assay is based on reduction of organic peroxide, which produces oxidised glutathione (GSSG) immediately reduced to GSH by GR with concomitant oxidation of NADPH to NADP+ and a decrease in absorbance at $340 \mathrm{~nm}$. The absorbance decrease was measured spectrophotometrically, and it is directly proportional to the GPx activity in the sample. The extinction coefficient for NADPH at $340 \mathrm{~nm}$ is $6220 \mathrm{M}^{-1} \mathrm{~cm}^{-1}$. One unit of GPx activity causes the oxidation of $1 \mu \mathrm{mol}$ of NADPH per minute under the assay conditions.

Glutathione S-transferase activity was measured using Glutathione S-Transferase Assay Kit (Cayman Chemical Company, Ann Arbor, MI, USA). The assay utilises the conjugation of CDNB (1-chloro-2,1-dinitrobenzene) and GSH accompanied by an increase in absorbance at $340 \mathrm{~nm}$. The extinction coefficient for CDNB at $340 \mathrm{~nm}$ is $0.0096 \mu \mathrm{M}^{-1} \mathrm{~cm}^{-1}$. One unit of GST will conjugate $1 \mathrm{nmol}$ of CDNB with GSH per minute at $25^{\circ} \mathrm{C}$.

Glutathione reductase activity was determined using the BIOXYTECH ${ }^{\circledR}$ GR-340 ${ }^{\mathrm{TM}}$ Assay (OXIS International, Inc., Foster City, CA, USA). The assay is based on catalysed reduction of GSSG to GSH and oxidation of NADPH to NADP ${ }^{+}$. The oxidation of NADPH results in a decrease of absorbance at $340 \mathrm{~nm}$ as a function of time. The molar extinction coefficient for NADPH at $340 \mathrm{~nm}$ is $6220 \mathrm{M}^{-1} \mathrm{~cm}^{-1}$. One unit of GR activity is defined as the amount of enzyme catalysing the reduction of $1 \mu \mathrm{mol}$ of GSSG per minute under assay conditions.

Total GSH concentration was determined by the BIOXYTECH ${ }^{\oplus}$ GSH-420 ${ }^{\text {TM }}$ Assay (OXIS International, Inc., Foster City, CA, USA). The measurement is based on a three-step colourimetric reaction. The reducing agent, TCEP (Tris[2-carboxyethyl] phosphine), reduces all oxidised glutathione present in the sample. In the next step chromogen (4-chloro-1-methyl-7-trifluoromethylquinolinium methylsulfate) is added, reacting with all thiols in the sample and forming thioethers. $\mathrm{NaOH}$ raises the $\mathrm{pH}$ of the reaction mixture to over 13 and leads to chromophoric thione development as a result of $\beta$-elimination specific to the GSH-thioether. The absorbance measured at $420 \mathrm{~nm}$ is directly proportional to the GSH concentration.
Total MDA concentration was determined using BIOXYTECH ${ }^{\oplus}$ MDA-586 ${ }^{\text {TM }}$ Assay (OXIS International, Inc., Foster City, CA, USA). The protocol is based on hydrolysis of the sample in the presence of butylated hydroxytoluene (BHT) at low pH (1-2) at $60^{\circ} \mathrm{C}$ for $80 \mathrm{~min}$. After hydrolysis, free MDA reacts with the chromogenic reagent ( $N$-methyl2-phenylindole, $\mathrm{NMPI}$ ) for $60 \mathrm{~min}$ at $45^{\circ} \mathrm{C}$. The reaction yields a carbocyanine dye that can be detected at $586 \mathrm{~nm}$.

The enzyme activities were expressed as units $(\mathrm{U})$ or $\mathrm{mU}$ per milligram of proteins $(\mathrm{U} / \mathrm{mg}$ or $\mathrm{mU} / \mathrm{mg})$. Concentration of GSH and MDA were expressed as nmol/mg of proteins.

\section{Statistical analysis}

Statistical analysis was performed with SPSS 23.0 for Windows (SPSS Inc., Chicago, IL, USA). The OS rate was calculated by Kaplan-Meier method, and groups were compared using Log-rank statistics. The compared groups of AO parameters were made by cut-off points based on median value of enzyme activity or MDA and GSH concentration, as previously reported [16]. Univariate and multivariate Cox proportional hazards regression model were used to analyse the independent factors related to 5-year OS. $P$-values $<0.05$ were considered significant.

\section{Results}

\section{Clinical findings}

Clinicopathological characteristics of patients are given in Table I. The majority of patients were between ages 61 and 70 years, and both genders were almost equally represented. The median tumour size was $7 \mathrm{~cm}(\mathrm{IQR}=5-8.2 \mathrm{~cm})$. The majority of tumours were up to $7 \mathrm{~cm}$ in diameter (63.1\%). Low-grade (I-II) RCC was diagnosed in the majority of patients. Stages 1 and 3 were most frequently recorded, and ccRCC was the most common histological subtype at the time of diagnosis.

\section{Survival analysis}

The OS for all patients was $96.8 \%, 73.7 \%$, and $54.6 \%$ after 1, 3, and 5 years, respectively (Figure 1 A). Statistically significant correlations existed between survival and age (log-rank 13.999, $p=0.003)$, tumour size (log-rank, 22.540, $p<0.001$ ), grade (log-rank 12.080, $p=0.001$ ), and stage (logrank 26.217, $p<0.001$ ) (Figures $1 \mathrm{~B}-\mathrm{E}$ ).

In each age group the 5 -year OS rate was as follows: $84.6 \%$ among patients younger than 50 years, $70 \%$ among patients aged $51-60$ years, $33.9 \%$ among patients aged between $61-70$ years, and $61.8 \%$ among those older than 70 years (Figure $1 \mathrm{~B})$. The rates of OS after 1,3 , and 5 years for 
patients with RCC size $\leq 4 \mathrm{~cm}$ were $100 \%, 77.8 \%$, and $70.7 \%$, respectively; patients with tumour size $4.1-7 \mathrm{~cm}$ had survival rates of $97.6 \%, 87.7 \%$, and $70.4 \%$ after 1,3 , and 5 years. After 5 years of follow-up, $60.2 \%$ of patients with RCC size $7.1-10 \mathrm{~cm}$ were still alive. None of the patients with tumour size $>10 \mathrm{~cm}$ were alive after 5 years (Figure $1 \mathrm{C}$ ).

After 5 years, survival among subjects with low-grade tumours was $64.3 \%$. In the high-grade tumour group, the survival rate was 96.6, 55.2, and $34.5 \%$ after 1,3 , and 5 years, respectively (Figure 1 D). Patients with low-stage tumours (stage 1 and 2) had survival rates of $77.2 \%$ and $77.9 \%$, respectively, while $34 \%$ of patients with stage 3 were alive after a 5 -year follow-up period. None of the patients with stage 4 RCC were alive after 5 years (Figure $1 \mathrm{E}$ ). As regards histological subtypes, after 5 years the better survival rate $(61.4 \%)$ was observed in patients with ccRCC compared to those with the pRCC (36.9\%), while chRCC patients showed survival rates of $100 \%$, $64.3 \%$, and $0 \%$ after 1,3 , and 5 years, respectively (Figure $1 \mathrm{~F}$ ). There was no significant association between gender, histological subtype, and survival rate (log-rank 0.002; $p=0.962$, log-rank 2.424, $p=0.298$, respectively).

The OS analysis based on the AO enzymes (Table II) revealed no statistically significant difference between the median values in survival rates. Also, Kaplan-Meier test showed no significant influence of lipid peroxidation parameter (MDA) and GSH concentration on survival of RCC patients.

Univariate analysis (Table III) showed that size, Fuhrman grade, and stage were significant prognostic factors for OS. The size $(>10 \mathrm{~cm})$ and high Fuhrman grade (III-IV) remained independent predictors of survival in multivariate analysis. Age, as a confounding variable, was excluded from the analysis.

\section{Discussion}

Oxidative stress plays a crucial role in the pathogenesis of various malignancies, including RCC. ROS can induce the carcinogenesis process and sustain tumour progression by damaging DNA and can directly activate cellular pathways of signal transduction, which are associated with malignant transformation. It was previously demonstrated that changes occurred in the oxidative stress/antioxidant status balance at the cellular level during the tumour growth process $[17,18]$. Previous studies have shown significantly reduced expression and activity of $\mathrm{AO}$ enzymes in cancerous tissue of the kidneys [19, 20]. Moreover, the enzymatic source of ROS is overactive [21] resulting in increased level of oxidative stress in patients with RCC [22-25]. Based
Table I. Clinicopathological characteristics of patients with renal cell carcinoma $(N=95)$

\begin{tabular}{|c|c|}
\hline Characteristic & $\begin{array}{c}\text { Occurrence } \\
N(\%)\end{array}$ \\
\hline \multicolumn{2}{|l|}{ Age: } \\
\hline$\leq 50$ & 17 (17.9) \\
\hline $51-60$ & $18(18.9)$ \\
\hline $61-70$ & $43(45.3)$ \\
\hline$>70$ & 17 (17.9) \\
\hline \multicolumn{2}{|l|}{ Gender: } \\
\hline Male & $51(53.7)$ \\
\hline Female & $44(46.3)$ \\
\hline \multicolumn{2}{|c|}{ Size of tumour [cm]: } \\
\hline$\leq 4$ & $18(18.9)$ \\
\hline $4.1-7$ & $42(44.2)$ \\
\hline $7.1-10$ & $18(18.9)$ \\
\hline$>10$ & 17 (17.9) \\
\hline \multicolumn{2}{|l|}{ Grade: } \\
\hline Low & $66(69.5)$ \\
\hline High & $29(30.5)$ \\
\hline \multicolumn{2}{|l|}{ Stage: } \\
\hline 1 & 37 (38.9) \\
\hline 2 & $14(14.7)$ \\
\hline 3 & $40(42.1)$ \\
\hline 4 & $4(4.2)$ \\
\hline \multicolumn{2}{|l|}{ Histology: } \\
\hline Clear cell & $74(77.9)$ \\
\hline Papillary & $13(13.7)$ \\
\hline Chromophobe & $8(8.4)$ \\
\hline
\end{tabular}

on these findings, permanent oxidative stress is a feature of RCC.

Prognostic significance of $\mathrm{AO}$ enzyme activities, MDA, and GSH levels in patients with RCC was not confirmed in this study. However, we observed a prospective influence of GPx, GR, and GSH on survival. Studies indicate the importance of GSH and its metabolising enzyme, $\gamma$-glutamyl transferase (GGT), which were found to be elevated in pathological states of oxidative stress and linked to tumour growth and survival. Glutathione is a major cell provider of cysteine, which is especially critical for protein synthesis in rapidly dividing neoplastic cells [26]. The study of Hofbauer et al. [27] showed that pretherapeutic 
A

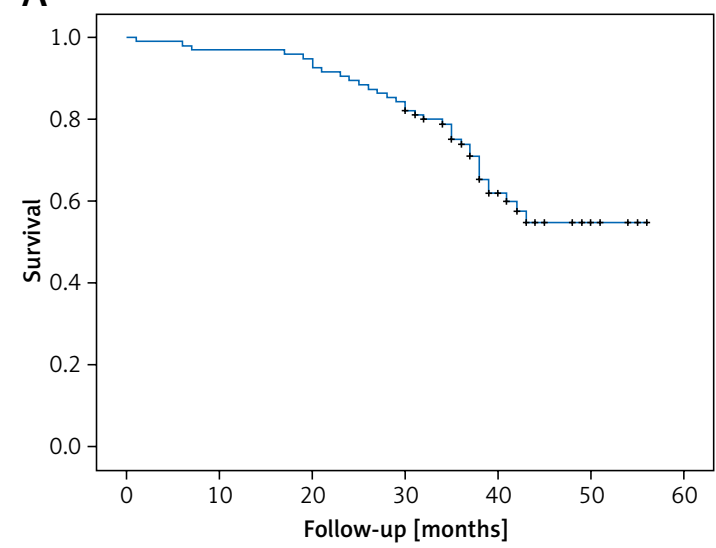

C

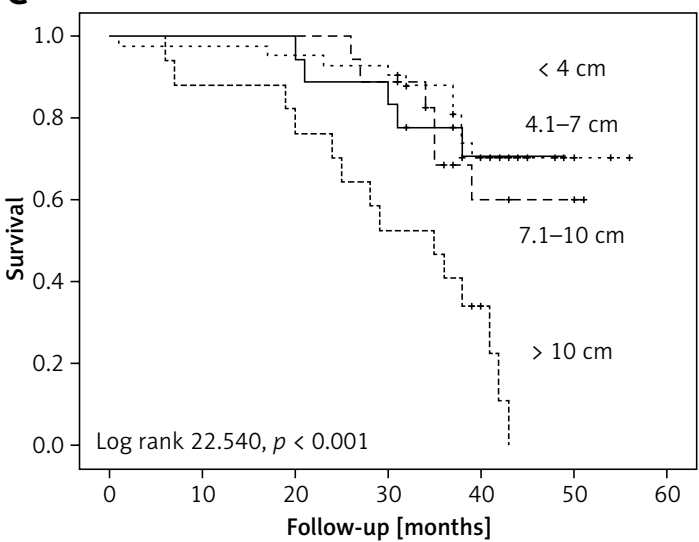

E

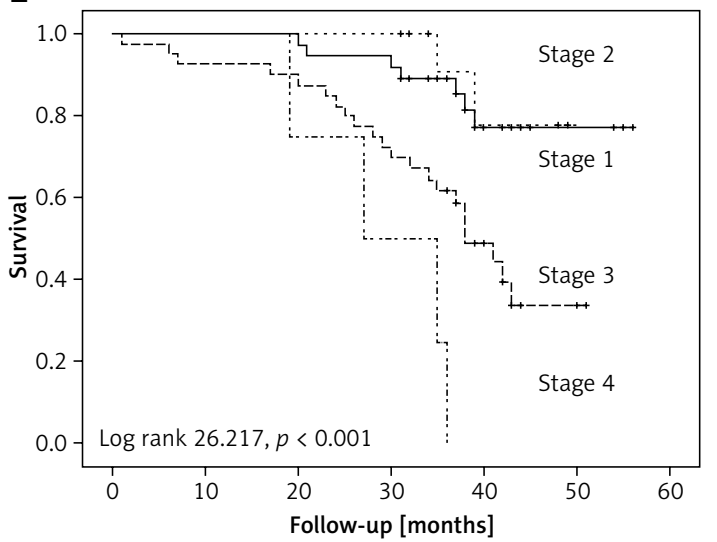

B

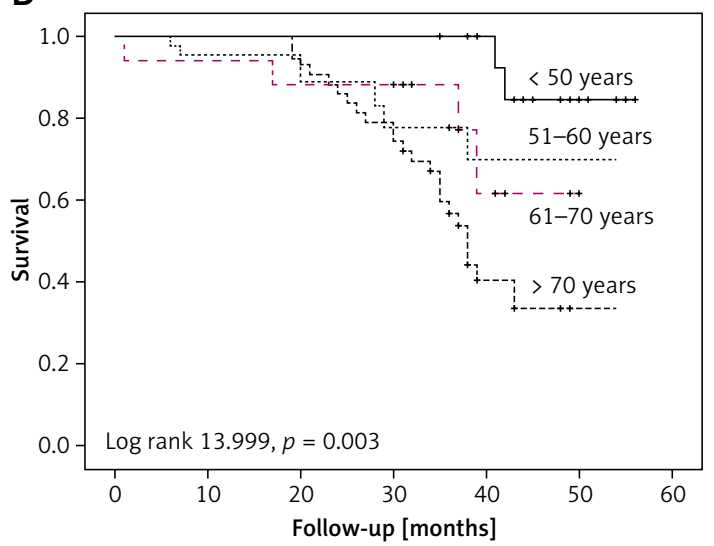

D

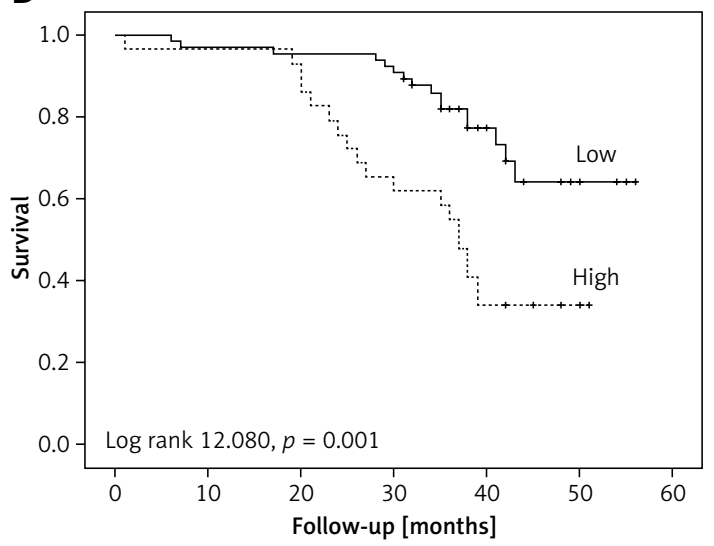

$\mathrm{F}$

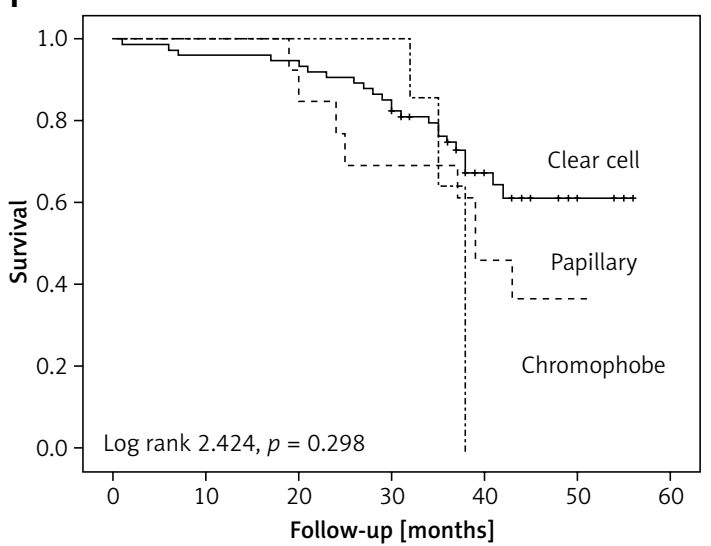

Figure 1. Survival in 95 patients with renal cell carcinoma. A - overall survival; survival according to: age (B), tumour size $(\mathbf{C})$, Fuhrman grade (D), stage $(\mathbf{E})$, histological subtype (F)

serum GGT was an independent prognostic factor for patients with RCC, with higher levels being associated with worse outcomes. It was shown that contrary to enzyme expression on the luminal surface of secretory and absorptive cells in normal kidney tissue, GGT is expressed over the entire cell surface in RCC. This may subsequently lead to elevated levels of GGT and higher intracellular levels of GSH, which correlate with the tumour burden [27]. However, Ganesamoni et al [22] observed a lower glutathione concentration in association with higher grade RCC and metastatic disease.

Earlier studies also show different results regarding other AO parameters in RCC. Glutathione peroxidase activity in RCC tissue was reported to be significantly decreased in one study [20] whereas it was unchanged in another [25]. 
The lipid peroxidation level was found to be higher in RCC than in normal renal tissue, and higher tumour grade was associated with increased lipid peroxidation in tumour tissue [22]. Vieira de Ribeiro et al. [28] found overexpression of SOD-1 in CCRCC extracts, which was explained by the fact that the production of ROS is generally more active in malignant cells. Although higher SOD level and lower CAT in tumour tissue were reported [22], no association of SOD level, histopathological findings, tumour grade, and stage was observed. Some recent findings suggest no correlation between tumour staging and serum levels of SOD, GPx, GST, MDA, and GSH levels [29]. In our study, we did not observe an association between GST level and OS; however, other investigators considered GST to be a highly specific diagnostic marker for primary conventional RCC, in which it is a prognostic marker if the grade is omitted from the multivariate analysis [30].

The findings of this study indicate that the 5 -year OS was $\sim 55 \%$, and it was within the range of contemporary data [3]. In univariate analysis, tumour size, pathological stage, and Fuhrman grade were independent predictors of OS. The size and grade remained significantly associated with OS after multivariate analysis. The Kaplan-Meier analysis indicated a possible role of the antioxidant GPx/GR activity and the GSH content for OS in these patients because the obtained significance values were near borderline.

Tumour size is considered as an important determinant of the UICC/AJCC (International Union Against Cancer/American Joint Commission on Cancer) TNM stage, which correlates with renal sinus invasion, metastatic potential, and RCC prognosis [31]. In our patients, the tumours with worse prognosis were larger than $7 \mathrm{~cm}$. The risk of death for patients with tumour size of $7.1-10 \mathrm{~cm}$ and $>10 \mathrm{~cm}$ was 1.2 and 4.1 times higher, respectively. Studies on large cohorts have shown that in patients with $c C R C C$, each $1 \mathrm{~cm}$ increase in tumour size increased the odds of a high Fuhrman grade (III-IV) compared with a low Fuhrman grade (I-II) tumour by $25 \%$ [32]. Although tumour stage was a prognostic marker affecting survival, it was not proven to be an independent parameter in multivariate analysis. The prognostic value of tumour grade observed in our study is in accordance with previous data. Most authors agree that Fuhrman grade and tumour stage are the strongest independent prognostic factors for RCC [33-36].

Some limitations of our study need to be addressed. It is likely that the relatively small number of analysed cases (95 patients) and group heterogeneity may have underestimated the prognostic effect of tumour stage, because the
Table II. Kaplan-Meier analysis of antioxidant status parameters in patients with renal cell carcinoma

\begin{tabular}{|c|c|c|}
\hline $\begin{array}{l}\text { Oxidant/AO } \\
\text { parameter } \\
(>/ \leq \text { median value })\end{array}$ & Log-rank & $P$-value \\
\hline \multicolumn{3}{|l|}{ SOD [U/mg]: } \\
\hline$\leq 59.38$ & 2.373 & 0.123 \\
\hline \multicolumn{3}{|l|}{$>59.38$} \\
\hline \multicolumn{3}{|l|}{ CAT [U/mg]: } \\
\hline$\leq 10.22$ & 2.418 & 0.120 \\
\hline \multicolumn{3}{|l|}{$>10.22$} \\
\hline \multicolumn{3}{|l|}{ GPx $[\mathrm{mU} / \mathrm{mg}]:$} \\
\hline$\leq 3.36$ & 3.506 & 0.061 \\
\hline \multicolumn{3}{|l|}{$>3.36$} \\
\hline \multicolumn{3}{|l|}{ GST [mU/mg]: } \\
\hline$\leq 3.33$ & 0.907 & 0.341 \\
\hline \multicolumn{3}{|l|}{$>3.33$} \\
\hline \multicolumn{3}{|l|}{$\mathrm{GR}[\mathrm{mU} / \mathrm{mg}]:$} \\
\hline$\leq 7.53$ & 3.063 & 0.080 \\
\hline \multicolumn{3}{|l|}{$>7.53$} \\
\hline \multicolumn{3}{|l|}{ GSH [nmol/mg]: } \\
\hline$\leq 58.26$ & 3.488 & 0.062 \\
\hline \multicolumn{3}{|l|}{$>58.26$} \\
\hline \multicolumn{3}{|l|}{ MDA [nmol/mg]: } \\
\hline$\leq 2.03$ & 0.208 & 0.648 \\
\hline$>2.03$ & & \\
\hline
\end{tabular}

tumour stage is among the most recognised prognostic factors. A larger sample size would also provide a better evaluation of the potential prognostic significance of $\mathrm{AO}$ parameters, judging by certain borderline significances observed in this study.

In conclusion, in our cohort of patients, we identified histopathological features of tumours as independent prognostic factors in RCC. No correlation was observed between $\mathrm{AO}$ status and OS. New studies are needed to provide better insight into cellular biology of oxidation and $\mathrm{AO}$ defence mechanisms, aiming to find prognostic biomarkers for patients with RCC.

\section{Acknowledgments}

This work was financially supported by the Ministry of Education, Science, and Technological Development of the Republic of Serbia (Grant III 41027). 
Table III. Factors affecting overall survival in patients with renal cell carcinoma

\begin{tabular}{|c|c|c|c|c|}
\hline Variable & Coefficient $\beta$ & $\mathrm{HR}$ & $95 \% \mathrm{Cl}$ & $P$-value \\
\hline \multicolumn{5}{|l|}{ Univariate analysis } \\
\hline Size of tumour $[\mathrm{cm}]$ : & & & & $<0.001$ \\
\hline$\leq 4$ & & 1.0 & - & \\
\hline $4.1-7$ & -0.213 & 0.808 & $0.276-2.370$ & 0.698 \\
\hline $7.1-10$ & 0.152 & 1.164 & $0.354-3.828$ & 0.803 \\
\hline$>10$ & 1.417 & 4.124 & $1.482-11.476$ & 0.007 \\
\hline \multicolumn{5}{|l|}{ Grade: } \\
\hline Low & & 1.0 & - & \\
\hline High & 1.115 & 3.051 & $1.567-5.941$ & 0.001 \\
\hline Stage: & & & & $<0.001$ \\
\hline 1 & & 1.0 & - & \\
\hline 2 & -0.302 & 0.739 & $0.154-3.560$ & 0.707 \\
\hline 3 & 1.280 & 3.596 & $1.535-8.424$ & 0.003 \\
\hline 4 & 2.473 & 11.861 & $3.353-41.959$ & $<0.001$ \\
\hline \multicolumn{5}{|l|}{$\mathrm{GPx}[\mathrm{mU} / \mathrm{mg}]$} \\
\hline$\leq 3.36$ & & 1.0 & & \\
\hline$>3.36$ & 0.649 & 1.9 & $0.954-3.841$ & 0.068 \\
\hline \multicolumn{5}{|l|}{$\mathrm{GR}[\mathrm{mU} / \mathrm{mg}]:$} \\
\hline$\leq 7.53$ & & 1.0 & & \\
\hline$>7.53$ & 0.598 & 1.819 & $0.918-3.604$ & 0.087 \\
\hline \multicolumn{5}{|l|}{$\overline{\mathrm{GSH}}[\mathrm{nmol} / \mathrm{mg}]:$} \\
\hline$\leq 58.26$ & & 1.0 & & \\
\hline$>58.26$ & 0.650 & 1.916 & $0.952-3.854$ & 0.068 \\
\hline \multicolumn{5}{|l|}{ Multivariate analysis } \\
\hline Size of tumour $[\mathrm{cm}]$ : & & & & 0.023 \\
\hline$\leq 4$ & & 1.0 & & \\
\hline $4.1-7$ & -1.027 & 0.358 & $0.109-1.172$ & 0.090 \\
\hline $7.1-10$ & -1.030 & 0.357 & $0.087-1.468$ & 0.153 \\
\hline$>10$ & 0.341 & 1.406 & $0.4-5.2$ & 0.611 \\
\hline \multicolumn{5}{|l|}{ Grade: } \\
\hline Low & & 1.0 & - & \\
\hline High & 1.469 & 4.345 & $1.915-9.862$ & $<0.001$ \\
\hline Stage: & & & & 0.101 \\
\hline 1 & & 1.0 & - & \\
\hline 2 & -0.080 & 0.923 & $0.174-4.900$ & 0.925 \\
\hline 3 & 1.197 & 3.309 & $1.123-9.750$ & 0.030 \\
\hline 4 & 0.829 & 2.290 & $0.424-12.368$ & 0.335 \\
\hline
\end{tabular}




\section{Conflict of interest}

The authors declare no conflict of interest.

\section{References}

1. Eble JN, Togashi K, Pisani P. Renal cell carcinoma. In: Pathology and Genetics of Tumours of the Urinary System and Male Genital Organs. Eble JN, Sauter G, Epstein J, Sesterhenn IA (eds.). IARC Press, Lyon 2004; 12-87.

2. Scelo G, Hofmann JN, Banks RE, et al. International cancer seminars - a focus on kidney cancer. Ann Oncol 2016; 27: 1382-85.

3. Znaor A, Lortet-Tieulent J, Laversanne $M$, Jemal $A$, Bray F. International variations and trends in renal cell carcinoma incidence and mortality. Eur Urol 2015; 67: 519-30.

4. Domagała-Haduch $M$, Cedrych I, Jasiówka $M$, Niemiec M, Skotnicki P. Analysis of adverse events of sunitinib in patients treated for advanced renal cell carcinoma. Arch Med Sci 2016; 12: 360-4.

5. Badowska-Kozakiewicz AM, Budzik MP, Koczkodaj P, Przybylski J. Selected tumor markers in the routine diagnosis of chromophobe renal cell carcinoma. Arch Med Sci 2016; 12: 856-63.

6. Zhao JJ, Chen PJ, Duan RQ, Li KJ, Wang YZ, Li Y. miR-630 functions as tumor oncogene in renal cell carcinoma. Arch Med Sci 2016; 12: 473-8.

7. Brown SA. Oxidative stress and chronic kidney disease. Vet Clin North Am Small Anim Pract 2008; 38: 157-66.

8. Shanmugasundaram K, Block K. Renal carcinogenesis, tumor heterogeneity, and reactive oxygen species: tactics evolved. Antioxid Redox Signal 2016; 25: 685-701.

9. Cano-Europa E, Blas-Valdivia V, Franco-Colin M, OrtizButron R. Regulation of the redox environment. In: Basic Principles and Clinical Significance of Oxidative Stress. Gowder SJT (ed.). InTech, Rijeka 2015; 3-15.

10. Frederiks WM, Bosch KS, Hoeben KA, van Marle J, Langbein S. Renal cell carcinoma and oxidative stress: the lack of peroxisomes. Acta Histochem 2010; 112: 364-71.

11. Qin WS, Deng YH, Cui FC. Sulforaphane protects against acrolein-induced oxidative stress and inflammatory responses: modulation of Nrf-2 and COX-2 expression. Arch Med Sci 2016; 12: 871-80

12. Rodriguez-Vida A, Strijbos M, Hutson T. Predictive and prognostic biomarkers of targeted agents and modern immunotherapy in renal cell carcinoma. ESMO Open 2016; 1: e000013.

13. Pejić S, Todorović A, Stojiljković V, et al. Antioxidant status and sex hormones in women with simple endometrial hyperplasia. In: Basic Principles and Clinical Sig nificance of Oxidative Stress. Gowder SJT (ed.). InTech, Rijeka 2015; 243-79.

14. Fuhrman SA, Lasky LC, Limas C. Prognostic significance of morphologic parameters in renal cell carcinoma. Am J Surg Pathol 1982; 6: 655-64.

15. Beutler E. Catalase. In: Red Cell Metabolism, a Manual of Biohemical Methods. $3^{\text {rd }}$ ed. Beutler E (ed.). Grune and Stratton, Orlando 1984; 105-6.

16. Javidroozi M, Zucker S, Chen WT. Plasma seprase and DPP4 levels as markers of disease and prognosis in cancer. Dis Markers 2012; 32: 309-20.

17. Ridge CA, Pua BB, Madoff DC. Epidemiology and staging of renal cell carcinoma. Semin Intervent Radiol 2014 31: 3-8.

18. Hatem E, Azzi S. Oxidative stress in carcinogenesis and therapy. J Cell Signal 2015; 1: 102.
19. Soini Y, Kallio JP, Hirvikoski P, et al. Antioxidant enzymes in renal cell carcinoma. Histol Histopathol 2006; 21: 157-65.

20. Pljesa-Ercegovac M, Mimic-Oka J, Dragicevic D, et al. Altered antioxidant capacity in human renal cell carcinoma: role of glutathione associated enzymes. Urol Oncol 2008; 26: 175-81.

21. Block K. Oxidative stress and redox-signaling in renal cell cancer. In: Emerging Research and Treatments in Renal Cell Carcinoma. Amato R (ed.). InTech, Rijeka 2012; 137-66.

22. Ganesamoni R, Bhattacharyya S, Kumar S, et al. Status of oxidative stress in patients with renal cell carcinoma. J Urol 2012; 187: 1172-6.

23. Gago-Dominguez M, Castelao JE. Lipid peroxidation and renal cell carcinoma: further supportive evidence and new mechanistic insights. Free Radic Biol Med 2006; 40: 721-33.

24. Soini Y, Kallio JP, Hirvikoski P, et al. Oxidative/nitrosative stress and peroxiredoxin 2 are associated with grade and prognosis of human renal carcinoma. APMIS 2006; 114: 329-37.

25. Lusini L, Tripodi SA, Rossi R, et al. Altered glutathione anti-oxidant metabolism during tumor progression in human renal-cell carcinoma. Int J Cancer 2001; 91: 55-9.

26. Castellano I, Merlino A. Gamma-glutamyl Transpeptidases: Structure and Function. Springer, Basel 2013.

27. Hofbauer SL, Stangl KI, De Martino M, et al. Pretherapeutic gamma-glutamyltransferase is an independent prognostic factor for patients with renal cell carcinoma. Br J Cancer 2014; 111: 1526-31.

28. Vieira de Ribeiro AJ, Sandim V, Ornellas AA, Reis RS, Domont G, Alves G. Differencial proteome of clear-cell renal cell carcinoma (ccRCC) tissues. Int Braz J Urol 2013; 39: 83-94.

29. Pirinççi N, Kaba M, Geçit I, et al. Serum prolidase activity, oxidative stress, and antioxidant enzyme levels in patients with renal cell carcinoma. Toxicol Ind Health 2016; 32: 193-9.

30. Searchfield L, Price SA, Betton G, Jasani B, Riccardi D, Griffiths DFR. Glutathione S-transferases as molecular markers of tumour progression and prognosis in renal cell carcinoma. Histopathology 2011; 58: 180-90.

31. Samaratunga H, Gianduzzo T, Delahunt B. The ISUP system of staging, grading and classification of renal cell neoplasia. J Kidney Cancer VHL 2014; 1: 26-39.

32. Thompson RH, Kurta JM, Kaag $M$, et al. Tumor size is associated with malignant potential in renal cell carcinoma cases. J Urol 2009; 181: 2033-6.

33. Motzer RJ, Mazumdar M, Bacik J, Berg W, Amsterdam A, Ferrara J. Survival and prognostic stratification of 670 patients with advanced renal cell carcinoma. J Clin Oncol 1999; 17: 2530-40.

34. Volpe A, Patard JJ. Prognostic factors in renal cell carcinoma. World J Urol 2010; 28: 319-37.

35. Flanigan RC, Polcari AJ, Hugen CM. Prognostic variables and nomograms for renal cell carcinoma. Int J Urol 2011; 18: 20-31

36. Grivas N, Kafarakis V, Tsimaris I, Raptis P, Hastazeris K, Stavropoulos NE. Clinico-pathological prognostic factors of renal cell carcinoma: a 15-year review from a single center in Greece. Urol Ann 2014; 6: 116-21. 